\title{
Employment in the informal economy: implications of the COVID-19 pandemic
}

\author{
Aleksandra Webb and Ronald McQuaid \\ Management Work and Organisation Division, University of Stirling, \\ Stirling, UK, and \\ Sigrid Rand \\ Department of Human Geography, Goethe University Frankfurt, \\ Frankfurt am Main, Germany
}

Employment in the informal economy

1005

Received 2 August 2020 Revised 1 September 2020 Accepted 2 September 2020

\begin{abstract}
Purpose - Although the coronavirus (COVID-19) pandemic appears to disproportionately affect those in informal employment, they often receive less government support than the formally employed. This paper considers definitions of the informal economy and informal employment, explores the rationale for participating in the informal economy and reflects on some effects of the pandemic on these workers.

Design/methodology/approach - The paper presents a narrative literature review with analysis of the selected academic and policy literature.

Findings - There are considerable short- and long-term implications of the pandemic for informal employment and the informal economy. This occurs against the background of unresolved tensions arising from informal workers' desire for more employment security and employers' striving for continued labour flexibility while transferring costs to government and workers. The COVID-19 pandemic might accelerate current trends and force new solutions to better protect basic work security while helping organisations to remain competitive. Government policies supporting work safety, income security, moves to formalisation of employment and fairness for informal employees are particularly important.

Research limitations/implications - As statistical and qualitative evidence is currently limited, it is too early to identify the full effects of COVID-19 on employment in the informal economy.

Practical implications - The results suggest that governments need to carefully consider explicit support for those in informal employment to create fair, resilient and ethical structures for workers, businesses, economies and wider societies.

Social implications - The paper identifies some of the social implications of COVID-19 for the informal sector.

Originality/value - The analysis offers initial insights into the impacts of a major health, economic and social shock on informal working.
\end{abstract}

Keywords Informal economy, Informal employment, Gig economy, Pandemic, Coronavirus (COVID-19)

Paper type Research paper

\section{Introduction}

In March 2020, the spreading of the coronavirus (COVID-19) pandemic led the World Health Organization (WHO) to declare a global public health emergency. The policy responses taken

(C) Aleksandra Webb, Ronald McQuaid and Sigrid Rand. Published by Emerald Publishing Limited. This article is published under the Creative Commons Attribution (CC BY 4.0) licence. Anyone may reproduce, distribute, translate and create derivative works of this article (for both commercial and noncommercial purposes), subject to full attribution to the original publication and authors. The full terms of this licence may be seen at http://creativecommons.org/licences/by/4.0/legalcode

The authors wish to thank the anonymous referees for their helpful comments, which have improved the paper. They would also like to thank the members of the European Local Labour Market Monitoring Network and participants at their annual conference in 2019. The authors are grateful to the financial support from the University of Stirling for enabling this paper to be open access to all. All views and errors remain those of the authors.

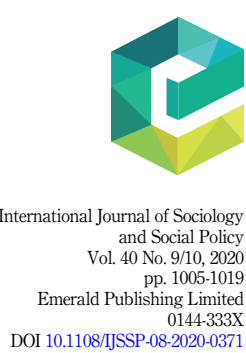

DOI 10.1108/IJSSP-08-2020-0371 
IJSSP

$40,9 / 10$

1006

by the governments, including lockdown measures, and the resulting economic downturn particularly affected certain sectors, which employ large numbers of employees and self-employed in both formal and informal economies. These sectors included bars and restaurants; arts, entertainment and other leisure providers; transport providers; accommodation and real estate businesses as well as travel agents and tour operators (ILO, 2020). With parts of many developed economies still not fully recovered even a decade after the 2008 financial crisis, governments worldwide have rushed to implement a range of approaches to manage this health crisis. Although the COVID-19 pandemic appears to disproportionately affect those in informal employment, they often receive less government support than the formally employed. This paper considers the informal economy and employment and reflects on some effects of the pandemic on these workers.

There remains uncertainty over the length and effects of this pandemic, or indeed whether consequent waves will reappear in months and years to come. Its impact will undoubtedly lead to many organisations closing or reducing their operations and their development will be greatly affected for many years. An increased debt burden and reduction of markets or a substantial loss of income experienced by employers has already had "knock-on" multiplier effects on others including their staff, suppliers, business collaborators and communities. In contrast, for other employers the crisis may spark a period of reinvention and adaptation, leading them to thrive as they take advantage of opportunities generated by the changes in the supply chain and consumer demand, activities and habits.

In many countries, such as the UK, the sectors of the economy most affected by COVID-19 in its early stages have been low-wage sectors which tend to disproportionately employ young people, women and those from ethnic and minority groups (Papoutsaki and Wilson, 2020). Moreover, many workers in these sectors are informally employed and have been unable to receive governmental financial support available to those employed in the formal economy (Williams and Kayaoglu, 2020a; ITUC, 2020). In economically developed countries, informal employment comprises nearly a fifth (18\%) of workers, but $61 \%$ of the global workforce (ILO, 2018a; Schneider et al., 2010). In the short-term the pandemic is likely to affect workers and job seekers with less social and employment protection, particularly those in the informal labour market. However, the longer-term effects on these and other types of workers remain unclear and could follow different trajectories. This paper seeks to explore some of the implications of the pandemic for employment in the informal economy, particularly in economically developed, or high-income, countries [1].

As discussed below, informal employment encompasses activities that are considered illegal or which do not follow employment and tax regulations, but are otherwise legal or legitimate. Additionally, informal employees in waged employment in informal jobs may include those in so-called non-standard or "alternative work arrangements", who are among those most affected by the pandemic. In the USA, Katz and Kreuger (2019) found that most recent jobs growth originated from such alternative work arrangements involving temporary help agency workers, on-call workers, contract company workers and independent contractors or freelancers. The share of such jobs rose from $10.7 \%$ to a range of $12.6 \%-$ $15.8 \%$ of jobs from 2005 to 2015 . These workers with similar characteristics and in similar occupations generally earned less per week than regular employees, mainly due to working (often involuntarily) fewer annual hours. As most informal employment relationships are associated with low quality employment and insufficient social protection, this trend makes collective action to improve working conditions difficult. It appears that the pandemic may have accelerated an existing trend towards a greater proliferation of non-traditional and "gig" jobs, and this may limit progress towards sustained "decent" work for all (UN Sustainable Development Goal No. 8, UN, 2017), which includes fair working conditions, equal opportunities and social protection (European Commission, 2017). 
First, this paper presents current definitional understandings of the informal economy phenomenon. Second, it discusses some key conceptual approaches to explaining participation in the informal economy, including the rationalities guiding the decisions of individual workers, organisations and businesses. Third, it considers the concept of "tax morale" to help understand the level of engagement with the informal economy and its potential to inform the design of interventions to tackle the informal economic activities and support individual and organisational actors in the transitions from informal to formal employment. Implications of COVID-19 for employment in the informal economy are discussed at the end of each section, and the paper finishes by highlighting some further directions for enriching the debate on the informal economy, particularly during a time of crisis.

\section{Informal employment and the informal economy}

There is a wide range of different terms used to refer to activities that are perceived to be part of the "informal economy", including: “"atypical”, "cash-in-hand”, "hidden”, "irregular", "non-visible", "shadow", "undeclared", "underground" and "unregulated"” (Williams and Martinez, 2014, p. 2). Such activities, and the incomes derived from them, can be undertaken by both individual workers and organisational employers or companies/business enterprises. Definitions often imply "shadow economy" activities that are not declared (to tax authorities) or take place in non-formalised space; essentially, reflecting a dichotomy of "open" and "hidden" spaces, as in the formal/informal classification of registered/unregistered or legitimate/illegal activities. For instance, Williams and Martinez (2014, p. 2), define informal employment as "unregistered by, or hidden from the state for tax and/or benefit purposes".

Importantly, Williams and Horodnic (2016a, b) add that the definition of informal economic activities should make a distinction between: "legitimate" informal activities, i.e. those that would be legal in the formal economy if appropriate regulations were followed and taxes paid etc.; and those that would be "illegal" and "illegitimate" in the formal economy, such as criminal activities (e.g. forced labour and drugs dealing). Furthermore, the ILO (2018a) argues that there is a distinction between employment in the informal sector and informal employment. The informal sector is defined in terms of the characteristics of the workplace of the worker, i.e. it is based on the organisation or enterprise. In contrast, informal employment is seen as a jobs-based concept, referring to the worker's job and the employment relationship and the associated employment protection. Hence employment in the informal economy combines "employment in the informal sector + informal employment outside of the informal sector (i.e. informal employment in the formal sector + informal employment in households)" (ILO, 2018a, p. 11). This ILO definition underlines the role of state regulation concerning the workplace as well as the employment relationship, i.e. rules and controls, which constitute the legitimate and permissible spheres of economic activities.

Thus, regulation by formal and informal institutions emerges as a central frame of analysis in the literature on informal economy. Portes and Haller (2005) argue that regulation delimits the opportunities and spaces for self-regulation of activities, and in the extreme the whole economy is subject to the "possibility of rule violation for profit" (p. 410). Hence, the informal economy can be understood as an income-generating production that avoids legal and social institutional regulations where similar production activities would be regulated (Dell'Anno, 2003). The scale of such work is significant with around $2.8 \%$ of workers in the European Union providing undeclared (to the authorities) services and a fifth of these (21\%) rely solely on such undeclared income (Williams and Kayaoglu, 2020a).

Williams and Horodnic (2016a) suggest that the informal economy is regulated, but by informal rather than formal institutions. Activities may be illegal from the viewpoint of formal institutions, but they may be perceived as socially legitimate from the viewpoint of 
IJSSP

$40,9 / 10$

1008 informal institutions. These sets of illegal, but to some, legitimate activities in the informal economy focus on the recognition and exploitation of business opportunities in the field of production and distribution (Castells and Portes, 1989; Portes and Haller, 2005, p. 405f; Webb et al., 2009).

Those working in the informal economy can be separated broadly into two categories of informal employment (ILO/WIEGO, 2019; Stuart et al., 2018; Chen, 2012; Hussmanns, 2004):

(1) Self-employed in informal enterprises (e.g. workers in small unregistered or unincorporated enterprises, including employers, own-account operators and unpaid family workers);

(2) Wage employed in informal jobs or informal employees (e.g. workers who work in the formal or informal firms or for households and do not have access to secure formal contracts, statutory workers' benefits, social protection or workers' representation; employees with no fixed employer and other informal wage workers such as casual or day labourers; domestic workers; industrial outworkers, notably home workers; unregistered or undeclared workers; and temporary or part-time workers).

With this definition, informal employment encompasses employment in the informal sector, in the formal sector and in households.

In contrast to the conventional approach that sees a clear dichotomy between formal and informal employment, Williams (2014, p. 8) suggests that a range of modalities exist: formal and informal waged works often overlap, blurring the distinction between formal and informal work. For example, in the instance of "envelope wages" formal waged employees, who work for formal employers, can sometimes be paid two distinct wages by these employers. They receive an official declared wage and an additional unofficial undeclared ("envelope") wage with cash for overtime and/or for the regular work conducted. As this arrangement results in a deliberate underpayment of taxes, it is outside regulations and illegal. Other examples are the various forms of profit-motivated self-employment ranging from the formally self-employed who conduct various portions of their trading as "cash-inhand" or "off-the-books" (including trade were the income is declared to the tax authorities), or a "false self-employment", where a self-employed person works for one employer only, but pays lower or no income tax compared to if they were a formal employee. Also, undeclared "paid favours" which are often conducted for and by kin relations living outside the household (e.g. friends, neighbours and acquaintances) for social and/or profit motivations also show the extent of the informal economy. Shapland and Heyes (2017) argue further that formalised employment in the UK has become more casualised and no longer provides significantly better benefits than informal jobs, which again blurs a clear distinction between the two.

The heterogeneous classification set out above might include individuals who may meet all the statutory tax and other regulations, but are classed as independent contractors providing their labour to either individuals or businesses (DBEIS, 2018, p. 12) and covering a variety of legal and legitimate jobs and sectors, such as:

(1) Individuals completing tasks using platforms which play an active role in facilitating work and take a proportion of the pay or charge providers fees for using the platform (e.g. Uber taxi drivers, TaskRabbit and PeoplePerHour);

(2) People providing services who are either freelancers or may have set up a one-person business to offer their services.

These examples demonstrate the need to expand the understanding of the informal economy to include "non-standard" work and workers or "alternative work arrangements", 
"contingent workers" and the "gig economy" (ILO, 2018a). The ILO lists the four main types of non-standard forms of employment as including: (1) temporary waged employment; (2) parttime waged employment with less than 35 weekly working hours; (3) temporary agency work and other forms of employment involving multiple parties and (4) disguised employment relationships and dependent self-employment. Non-standard forms of employment, such as temporary and part-time employment, are significantly more likely to be informal, which primarily manifests itself in the absence of social security coverage and employer's contributions gained through employment or through the absence of other forms of social protection such as paid annual or sick leave. This suggests differences in the appropriate scope of current regulations and their effective enforcement, including the issuing of employment contracts for temporary workers, or realistic qualifying thresholds of legal protections such as the length and amount of employment.

Worldwide, different forms of informal employment prevail depending on the level of socio-economic development, industrial infrastructure, regulatory capacities and administrative structures of the state as well as the social structure and cultural resources of the population (Portes and Haller, 2005, p. 410). Economically developed, high-income countries are not homogeneous and have different structures, tendencies and challenges than those observed in the low-income developing countries. For example, the economies of the countries making up the European Union differ in term of the size and character of the informal economy (Williams, 2014). William's classification of the EU Member States along the extent of formalisation of their economies detects a European North/South division. According to his analysis, Eastern/Southern countries display a higher share of informal economic activities than the Western/Nordic ones. While the former had a tendency towards "waged" informal economies, while in the latter informal "own-account" economic activities are more wide-spread.

When considering the varieties of informal employment, precariousness inherent to these employment relationships emerges in its different forms as a common denominator. However, it needs to be underlined that while there is a significant overlapping between precarious and informal employment, precarious employment is not always informal and vice-versa (e.g. in the developing country context employees can consider their informal employment relationships to be permanent, even if there is no formal contract). This is a crucial issue when considering the implications of the pandemic as informal workers may be able to take action that keeps them in employment, e.g. being paid below the statutory minimum. In these cases, remaining in employment possibly entails accepting worse terms and conditions (an "under-cutting of formal workers" argument).

The lack of job and income security in employment, due for instance to sudden short-term closures of firms and longer-term layoffs, is a major factor in the economic, health and psychological impact of the pandemic on different workers. The non-regulated aspect of the informal economy can lead to a fragile employment status for those who engage in informal economic actives and who are not protected by employment law and regulations or state agencies. Such was the experience of many workers during the initial impact of the pandemic, particularly those with no formal records of work undertaken and thus unable to access governmental support.

Contingent workers, on the other hand, are more commonly used in competitive market economies, to provide organisations with suitable, flexible labour when needed and without the burden of costly long-term wages (Robbins et al., 2017) and have been similarly affected by the pandemic. Such organisational strategies to increase their efficiency and competitiveness contribute to the development of (computer-based) platform economies (Howcroft and Bergvall-Karreborn, 2019); or the "gig economy" that "involves exchange of labour for money between individuals or companies via digital platforms that actively facilitate matching between providers and customers, on a short-term and payment by task 
IJSSP

$40,9 / 10$

1010 basis" (DBEIS, 2018, p. 12). The gig economy offers "short and in particular very short hours of work resulting in low levels of income may also lead to an exclusion from the scope of current social security laws if conditioned by a minimum level of earnings" (ILO, 2018a, p. 60). Hence the gig economy can be understood as a labour market characterised by the prevalence of short-term contracts (gigs) or freelance work. It has been viewed positively for offering flexible working hours (e.g. for students, carers, creative and independent professionals and underemployed) or criticised as a modern form of slavery and workers' exploitation (DBEIS, 2018; TUC, 2017).

While certain groups of workers indeed enjoy the benefits such flexible work can offer, other groups-particularly those working in the service sectors including those who aspire to have a full-time permanent job-often have little choice but to accept such short contracts with little protection by labour laws and regulations. A polarised pattern of either underemployment or excessive working hours, often outside normal working hours, have been heavily criticised by labour researchers. The ILO (2018a, p. 62) reports that both scenarios have negative consequences: "time related under-employment and a potentially higher risk of working poverty in the case of very short hours of work and exposure to higher health and safety risks in addition to work-life balance issues without due financial compensation in the case of excessive hours". The share of workers in the gig economy is higher among workers in informal economy compared to those in formal employment. However, the use of informal workers on lower wages and/or terms and conditions is also likely to result in poorer conditions for "formal" workers in competing firms.

There are a number of detrimental characteristics of workers in informal economy. On the one hand, organisations in the informal economy may be associated with low productivity, limited capacity for innovation and limited access to capital (De Beer et al., 2013). In effect, the surplus of capital arising from circumventing legal requirements of social security systems and environmental standards leads to a distorted competitive advantage that might undercut organisations in the formal sector and endanger the competitiveness of the latter (ILO, 2018b; Stuart et al., 2018).

On the other hand, informal economy can also be an integral part of highly innovative economic sectors, such as in the Italian system of flexibly specialised niche enterprises relying on "informally produced inputs and labor" (Portes and Haller, 2005, p. 407) to be able to react quickly to sudden peaks in demand and changing consumer preferences. Similarly, Sassen (1994, p. 2291) observed the growing diversification of the economy in terms of "jobs, firms and subcontracting patterns that induce or are themselves susceptible to informalization". While the growing income polarisation creates a need for customised products satisfying the exclusive taste and lifestyles of the higher-income classes, the needs of the low-income population are met by firms who keep the price of their products and services low by circumventing taxes and social security contributions (Sassen, 1994).

This tension between flexibility for the worker and for the employer (whether directly or indirectly through the services being contracted out) and security for the worker has been clearly exposed during the COVID-19 pandemic. Employers are able to cut their use of informal workers quickly without the formal procedures as they would need to take with formal employees. Thereby, they shift the costs of the unprecedented collapse in demand for product and services (due to lockdown regulations stopping the business producing and the public consuming) to a large extent to the workers. For the informal worker the flexibility may come at the cost of a sudden dramatic loss of income and sometimes a lack of ability to access formal employee support from the government, albeit that previously they had the "advantage" of paying less taxes or social security payments. In the next section, we explore the question of why individuals participate in the informal employment given the risks and cost associated with working in the informal economy. 
Who engages with the informal economy and why?

Employers (large corporations, small and medium business enterprises and other public/private organisations) and individual workers (freelance/self-employed/ entrepreneurs and organisational employees) each have different reasons for engaging with the informal economy. The motives for employers arise mostly from competition, financial constraints, lack of awareness and inappropriate understanding of compliance or a deliberate choice not to comply (ILO, 2015). Thus, it is clear that the economic activities in the informal economy can be hidden from the authorities and institutions not just for financial gain, but also to avoid regulatory responsibilities (Medina and Schneider, 2018; Williams, 2011; Webb et al., 2019). This includes entrepreneurial activities in the early stages of product development or trading when a higher risk of failure and financial loss is involved (Williams and Martinez, 2014). For example, the evidence from the UK suggests that owners of small businesses resort to informal trading when starting their business to test the viability of their product or service. While employers may have different reasons for engaging with the informal economy, they commonly arise from global and local competition rules and financial constraints (ILO, 2015).

The separation between formal and informal economies is often indistinct. As the nature of the entrepreneurial process is focused on the recognition and exploitation of business opportunities, decisions concerning growth often lead to activities on the periphery of or directly in the informal economy (Webb et al., 2009). This seems particularly the case for entrepreneurs oriented towards growing their ventures rather than those seeking a certain lifestyle or only supplementing their income. Using legitimacy theory, "a generalized perception or assumption that the actions of an entity are desirable, proper, or appropriate within some socially constructed system of norms, values, beliefs, and definitions" (Suchman, 1995, p. 574), suggests that entrepreneurs' definitions of an opportunity and the valuation of what constitutes legitimate action in the informal economy, will differ. Such valuation, for example, might lead to a decision to use undocumented or undeclared workers (e.g. illegal immigrants) to produce legal and legitimate products and activities such as house building, farm production or domestic services (Raijman, 2001); or usually legitimate but illegal products such as pirated music and counterfeit items (Givon et al., 1995).

It is especially important to recognise that engagement with the informal economy is not always an individual's choice, but rather a consequence of the informal institutions and practices as well as types of work individuals undertake; for example, temporary and seasonal jobs which are common in subsistence farming and other agricultural, horticultural and forestry jobs, domestic services, care, catering and tourism, retail etc. (Williams, 2020; Williams and Kayaoglu, 2020, a, b). As discussed above, these temporary/seasonal or precarious jobs are characterised by the absence of contracts and are short-lasting. These are predominantly labour-intensive low-technology sectors that employ low and unqualified workers (Schneider, 2011). The pandemic has greatly affected these types of, usually "customer-facing", activities and hence, informal workers are likely to be particularly affected by the pandemic at least in the short- and medium-terms.

\section{Participation and engagement with the informal economy}

There are several useful theoretical frameworks for explaining and understanding worker and employer participation in the informal economy in various sectors and contexts. Williams and Horodnic (2016a) set out three competing theories. First, modernisation theory explains the informal economy in terms of and the lack of economic development and modernisation of state bureaucracies (Lewis, 1959; cited in Williams and Horodnic, 2016a); second, "neo-liberal" approaches suggest that engagement in the informal economy is a response to extensive rules, burdensome regulations and perceived high taxes; while third,
Employment in the informal economy

1011 
IJSSP

$40,9 / 10$

1012 political economy theory argues that the informal economy results from inadequate state intervention and a lack of protection for workers (Castells and Portes, 1989; ILO, 2014).

These approaches, while useful in making distinctions between different national contexts and expectations of an ideal relationship between state, regulation and economic activities, have been criticised for failing to acknowledge the specific intrinsic motivations of individual actors who choose, or not, to participate in the informal economy. Some actors might opt for informal employment when the pay-off is greater than the expected cost, for example of being caught and punished, or when alternatives are worse (e.g. unemployment); others might want to choose to participate even if the costs outweigh the benefits (Kirchler, 2007; Murphy, 2005). However, the explanatory power of such distinctions between rational and irrational economic behaviours as motivators for engagement with the informal economy is limited.

An alternative understanding of varied behaviours of individual actors and populations has been proposed by institutional theory and the notion of "tax morale" (McKerchar et al., 2013). It suggests differences in levels of acceptability concerning participation in the informal economy as a result of asymmetry between the codified laws and regulations of a society's formal institutions (government morality or "state morale") and the unwritten socially shared norms, values and beliefs of the population that constitute its informal institutions (societal morality or "civic morale") (Williams and Horodnic, 2016a). The values, norms and beliefs of a society's informal institutions can either complement those of formal institutions or substitute their rules if incompatibility with the formal institutions occurs (North, 1990).

Two key propositions of institutional theory help to understand the dynamics between the informal and formal economies. First, symmetry between formal and informal institutions eliminates the need for activities in the informal economy. Second, the asymmetry between a society's formal institutions (government morality) and its informal institutions (societal morality), such as due to a lack of trust in government, feeds the activities in the informal economy. Hence the greater the asymmetry between government morality and societal morality, the greater is the propensity to participate in the informal economy (Williams and Horodnic, 2016a). In other words, this means that the lower the level of "tax morale", the higher is the asymmetry and the level of participation in the informal economy. The higher the tax morale, e.g. due to a greater state intervention in the form of higher taxes resulting in greater social expenditure and social benefits, the lower is the asymmetry and the level of participation in the informal economy.

Finding across a range of geographical contexts suggest that "tax morale" is usually lower among men, single people, the unemployed and self-employed, but increases with religiosity, age, perceived social status and income and is negatively related to years spent in formal education (Williams and Martinez, 2014). These insights can perhaps be useful for planning interventions focused on tackling the informal economy and supporting workers' transitions from informal to formal employment. Williams and Horodnic (2016b) argue that it is possible to reduce participation in the informal economy by using interventions such as: improving educational attainment, older people mentoring younger people and improving women's participation in the labour market. The COVID-19 pandemic may alter judgements concerning "tax morale" with people starting to reconsider the positive value and benefits of taxes for health and employment support deriving from the formal economy.

However, an alternative view (especially in places where government responses have been poor) might be that people are more willing to avoid the formal sector as they will feel they need to invest in their own personal resilience rather than rely on inadequate government intervention. Devising adequate governmental responses to individual judgements on the cost-gain balance is especially pertinent to sectors that are generally difficult to regulate, such as in personal and household services. In Spain, for example, the association Sedoac representing domestic and care workers urged the government to extend COVID-19 related 
financial support measures (e.g. tax exemptions or income schemes for vulnerable households) and to those workers not included in the general social security system (WIEGO, 2020). Similarly, scholars and activists in Italy published a petition drawing the attention to the exclusion of domestic and care workers from the government support scheme called "Cura Italia" (Università di Pisa 2020).

\section{Reducing reliance on the informal economy}

As already discussed, engagement with informal economic activities has multiple potential negative consequences for individuals, the formal economy and societies. It causes significant tax loss, reducing public revenues and thus income available for key public services and support, including social protection; it also contributes to poorer working conditions and unfair competition for legitimate businesses, weakening trade unions and collective bargaining (ILO, 2014; TUC, 2008). Based on European Union data and drawing upon institutional theory's two basic mechanisms for tackling institutional asymmetry, Williams and Horodnic (2016, a, b) propose addressing the problem by changes to informal and formal institutions. The first mechanism is based on the idea of disincentives (sanctions and penalties) to prevent socially legitimate but illegal activities, for example by communicating and improving the likelihood of detection through inspection (e.g. Hasseldine et al., 2007). However, such an approach can be counterproductive as it can undermine respect for the fairness of the system and thus reduce voluntary compliance leading to greater engagement in the informal economy (Murphy, 2005). The second mechanism highlights the need to intensify desirable legal behaviours and activities (Mathias et al., 2015), for example, through direct and indirect tax incentives. This approach, however, fails to fully resolve the issue of compliance and morality.

Williams and Horodnic (2016a) thus propose a different solution to reducing individual participation in the informal economy. This is focused on improving the tax morale" by shifting from a low-trust and low-commitment ("hard") policy approach to a high-trust and highcommitment ("soft") policy approach. While the former seeks compliance through tight rules and close monitoring, the latter aims to simultaneously develop self-regulation through an internal commitment to the norms, values and beliefs of the population ("societal morality") and compliance with the codified laws and regulations of formal institutions ("government morality"). It is unclear how the pandemic might affect this in different circumstances.

As discussed above, this approach requires changes to happen simultaneously at the level of the norms, values and beliefs held by the population (through tax education, public information campaigns, appeals) and at the level of formal institutions (through promotion of procedural fairness and trust building, procedural justice and redistributive justice). Such changes may take many years, or even generations, and not all groups in society may change at the same time, so other shorter-term policies are required. Hence other approaches may also be useful, such as seeking to change short-term behaviour including social exchange or AMO (ability, motivation and opportunity) (Appelbaum et al., 2000); or prospect theory, which suggests that people systematically overvalue their losses and undervalue their gains (Kahneman and Tversky, 1979), so encouraging people to re-evaluate their assessment of losses and potential gains that may result from entering or leaving the informal economy.

In terms of the welfare system, some structures have changed during the pandemic. For instance, in the UK, social welfare support has been provided to those previously ineligible, including many self-employed, as well as wage support across large parts of the economy and different types of firms [2]. More generally, consideration might be given to a form of guaranteed minimum level of income (such as a negative income tax, or a guaranteed allowance or income support, see for instance, McDonough and Morales, 2020) for all people in a country, including those in precarious work or those losing their income due to a pandemic. However, this may
Employment in the informal economy 
IJSSP

$40,9 / 10$

1014 require a revision of the concept of work and potential difficulties include low long-term levels of income, work-related incentives, the differences between individual's wealth and incomes, affordability, the effects on public expenditure and possible inequality effects if not accompanied by adequate other income support measures for those with greater needs (for example see: Simpson et al., 2017). How welfare policies change in the future is still uncertain, although they present opportunities to carefully adapt the economic system in line with the social principles of care and fairness. The long-term consequences of support given to workers who lost income, as well as changes in the levels of trust towards the government and its policies, remain to be seen. However, possible effects could include greater compliance and a decreased desire by individuals to participate in the informal economy.

\section{Discussion and conclusions}

This paper considered definitions related to the informal economy, why people and organisations might participate in it and reflected on some effects of the COVID-19 pandemic on these workers. It is too early to identify medium- to long-term effects of the pandemic as a risk of multiple waves of infection and availability of effective medical treatments such as vaccines remain unknown. However, it is clear that even in high-income economies the forms of engagement, and reasons for participating in informal economic activities, vary amongst different populations and socio-economic contexts. The distribution of power between employers and workers in the global labour market has been widely discussed and the deteriorating conditions of work and pay are increasingly on the agenda of trade unions and other advocacy agencies. The economic advantages of employing a cheaper (in wage and/or non-wage terms) workforce at the expense of such things as security of income, occupation health and safety and employee welfare including short or no contracts at all, are drivers of some employers' behaviours and actions and may be increased by the pandemic.

Even if individual actors, for example self-employed persons or entrepreneurs working on own account outside the regulatory or tax systems, can be encouraged to transit from the informal to formal employment, waged actors rarely have much choice as they have limited power to set the parameters of labour exchange. Williams' (2020) work using Euro-barometer data has already indicated the initial short-term impact of the pandemic on undeclared (to tax authorities) informal work.

The extreme reduction in jobs in 2020 due to the pandemic, and high uncertainty about the future due to the pandemic, has fundamentally shifted the balance of costs and benefits involved in informal employment. In particular, it may increase individuals' costs if formal or informal employment opportunities diminish rapidly and access to government employment support is unavailable, unlike for those in the formal economy. As discussed above, the negative effects of the pandemic may counter-balance savings in taxes avoided or evaded or flexibility in choice of working times etc. There are also wider psychological and socio-economic effects on individuals, communities and regions, suggesting that issues of employment availability, flexibility and security will remain important. These changes in the balance of individuals' costs and benefits are likely to remain for some time due to the uncertainty of the full effects of the pandemic on the economy and perceived changing risks of future pandemics.

Conversely, the pandemic may encourage some employers to move away from formal work, due to the opportunities for more flexible and rapid response to major shocks (like the pandemic) that informal arrangements allow for. Reinforcing this, small and medium sized enterprises, where informal jobs are concentrated, may also suffer disproportionately from disrupted supply chains: larger firms might be given preference for goods in limited supply leaving smaller ones unable to produce efficiently, or the supply chains might be fundamentally altered due to the pandemic. 
However, a result is likely to be greater unresolved tensions between informal workers' desire for greater income and job security on the one hand and, on the other, some employers' striving for continued labour flexibility in the face of pandemic-induced changing labour and customer demands. The contrast between employer-worker perspectives becomes particularly salient in the employers' attempt to transfer the risk/costs of such flexibility to government and workers. Therefore, it is crucial to consider how government policy, including labour market regulation and support for continued employment during a pandemic, can mediate between the different actors in the longer-term.

A question arises as to how employers can be incentivised to withdraw from informal practices and how the balance in the exchange of labour can be restored to build stronger foundations for resilient, fair, ethical, legal and legitimate activities in the labour market. As Williams and Horodnic (2016a) suggest, prospective interventions have much greater chance to be effective if they consider the dynamics of "tax morale" and simultaneously address changes needed to strengthen both formal and informal institutions. Optimistically, it might be that in this global pandemic, designing and implementing inclusive employment and welfare support measures increases and reinforces principles of fairness and care. The spillover of this process might transform attitudes and behaviours in the informal institutions and thus foster greater trust, belief and commitment to the rules and regulation in the formal economy.

Formal and informal employment is closely linked through the complex interplay of exchanges between formal and informal institutions and other actors. When formal regulations of employment are not followed through, work of an informal character may begin, which may blur the boundaries between these two contexts. By focusing on the perspective of individual actors (both employees and employers) taking part in the informal economy, their decisions and actions may be governed through different rationalities, often arising from the incompatibilities and contradictions within employment systems. Hence it would be interesting to further explore the connection between the informal economy and a broader social security and welfare system within specific national and international contexts which clearly surfaced during the pandemic (e.g. insufficient social security subsidies; treatment of undeclared workers and earnings; gender inequalities within the labour market; or lack of affordable childcare provisions forcing people to consider paid favours; or expensive health systems which in some countries may push people to accept extra and illegal work in case of illnesses and adequate health protection while working). In addition, this paper suggests that governments need to carefully consider support for those in informal employment, including bringing them into more formal employment with greater security and protection and with associated contributions to taxes and social security.

The reengineering of the post-COVID-19 pandemic economy may lead to a reconsideration of widely utilised employment practices that tend to reduce workers' conditions and health and safety protection, in order to gain a competitive advantage. On the one hand, the rise over recent decades of a modern version of the "gig-economy" (people working on the basis of short-terms jobs, often being self-employed) may increase with a greater desire for flexibility among employers. Most probably, their aversion to taking on staff may be further aggravated by the possibility of future health and economic disruptions. On the other hand, there may be countering effects as workers seeking greater job and health security and a more effective unemployment safety net. This type of "gig" or short-term work has a long history (MacDonald and Giazitzoglu, 2019; Webb et al., 2019). The notion of "day labourers" in many countries today echoes the "lump labour" idea from the last century, denoting dock workers standing in a queue to be hired for the day if they were needed by the employer, but not paid if they were not chosen. The past struggles for job security from such jobs may be repeated by "gig" workers who find themselves without security during the pandemicinduced economic crisis, or even further shocks to the economy due to short or long-term 
IJSSP

40,9/10

1016

financial, health, demographic and environmental pressures. Thus, for more resilient and sustainable economies and societies identification, preparation for and responding to these future risks may need changes to the welfare and income support systems.

The rise in home working and remote based operations due to the pandemic are likely to accelerate trends over coming years, potentially altering the balance between formal and informal employment. Social and childcare demands, often delivered informally, may also rise in response to greater home working. Increased online purchasing trends, accelerated by the pandemic, may increase informal subcontracting of work. Particularly in the times of long-term crisis, it is possible that formalised employment may become more casualised and no longer a provider of significantly better work conditions than informal jobs (Shapland and Heyes, 2017).

Further research is needed into how potential tensions in the informal economy between workers, governments and employers and other institutions are resolved in different contexts. While the short-term effects of the COVID-19 pandemic are complex and unclear, it is likely that long-term effects on informal and formal employment and on different groups in society will be considerable, potentially affecting economic polarisation; so thorough analysis of likely impacts on different demographic, ethnic, gender and other groups is required. Research also needs to consider the development of distributional effects of informal employment and the implications of these for our theoretical understanding of employment. Overall, the pandemic is changing the balance of benefits and costs of informal employment compared to formal employment for individual workers, governments and employers in various ways, but the future consequences for the relative balance of informal or formal employment remain uncertain.

\section{Notes}

1. The ILO (2018a) defines GNI per capita of high-income countries as above USD 12,236 (pp. $14 f$. and 76).

2. In the UK, welfare rules were changed to support businesses and individuals through tax reliefs and the Coronavirus Job Retention Scheme, or furlough scheme (HM Revenue and Customs, 2020), with some recipients not being eligible under normal circumstances, as they had not contributed to relevant parts of the social security system. Some $27 \%$ of the UK workforce and up to $80 \%$ in some industries are affected by the furlough (ONS, 2020).

\section{References}

Appelbaum, E., Bailey, T., Berg, P. and Kalleberg, A.L. (2000), Manufacturing Advantage: Why High Performance Work Systems Pay off, Cornell University Press, Ithaca, NY.

Castells, M. and Portes, A. (1989), "World underneath: the origins, dynamics, and effects of the informal economy", Portes, A., Castells, M. and Benton, L.A. (Eds), The Informal Economy. Studies in Advanced and Less Developed Countries. John Hopkins University Press, Baltimore, pp. 11-37.

Chen, M.A. (2012), The Informal Economy: Definitions, Theories and Policies, Working Paper No. 1, Women in Informal Employment: Globalizing and Organizing (WIEGO), available at: http:// www.wiego.org/sites/wiego.org/files/publications/files/Chen_WIEGO_WP1.pdf (accessed 22 August 2019).

De Beer, J., Fu, K. and Wunsch-Vincent, S. (2013), "The informal economy, innovation and intellectual property: concepts, metrics and policy considerations", WIPO Economics and Statistics Series, Economic Research Working Paper No. 10, available at: https:/www.wipo.int/edocs/pubdocs/ en/wipo_pub_econstat_wp_10.pdf (accessed 22 August 2019).

Dell'Anno, R. (2003), Estimating the Shadow Economy in Italy: A Structural Equation Approach, Working Paper 7, Department of Economics, University of Aarhus, Aarhus, pp. 1-37. 
Department for Business, Energy and Industrial Strategy (DBEIS) (2018), "The characteristics of those in the gig economy", Final Report, available at: https://assets.publishing.service.gov.uk/ government/uploads/system/uploads/attachment_data/file/687553/The_characteristics_of_ those_in_the_gig_economy.pdf (accessed 22 August 2019).

Employment in the informal economy

Givon, M., Mahajan, V. and Muller, E. (1995), "Software piracy: estimation of lost sales and the impact on software diffusion", Journal of Marketing, Vol. 59, pp. 29-37.

Hasseldine, J., Hite, P., James, S. and Toumi, M. (2007), "Persuasive communications: tax compliance enforcement strategies for sole proprietors", Contemporary Accounting Research, Vol. 24 No. 1, pp. 171-194.

HM Revenue and Customs (2020), "Coronavirus job retention scheme”, available at: https://www.gov. uk/government/collections/coronavirus-job-retention-scheme (accessed July 2020).

Howcroft, D. and Bergvall-Kåreborn, B. (2019), "A typology of crowdwork platforms", Work, Employment and Society, Vol. 33 No. 1, pp. 21-38.

Hussmanns, R. (2004), Defining and Measuring Informal Employment, International Labour Office, Geneva, available at: https://www.ilo.org/public/english/bureau/stat/download/papers/meas.pdf (accessed 22 August 2019).

International Labour Office (ILO) (2014), Transitioning from the Informal to the Formal Economy, Report V (1), ILO, Geneva, available at: https://www.ilo.org/wcmsp5/groups/public/_ed norm/_relconf/documents/meetingdocument/wcms_218128.pdf (accessed 22 August 2019).

International Labour Organization (ILO) (2015), World Employment and Social Outlook: The Changing Nature of Jobs, ILO, Geneva, available at: https://www.ilo.org/wcmsp5/groups/public/dgreports/—dcomm/—publ/documents/publication/wcms_368626.pdf (accessed 22 August 2019).

International Labour Organization (ILO) (2018a), Women and Men in the Informal Economy: A Statistical Picture, ILO, Geneva, available at: https://www.ilo.org/global/publications/books/ WCMS_626831/lang-en/index.htm (accessed 22 August 2019).

International Labour Organization (ILO) (2018b), Informality and Non-standard Forms of Employment, ILO, Geneva, available at: http://www.g20.utoronto.ca/2018/g20_paper_on_nse_and_ formalization_ilo.pdf (accessed 22 August 2019).

International Labour Organization (ILO) (2020), COVID-19 and the World of Work: Impact and Policy Responses, ILO, Geneva, available at: https://www.ilo.org/globval/topics/coronavirus (accessed May 2020).

International Labour Organization (ILO)/Women in Informal Employment: Globalizing and Organizing (WIEGO) (2019), "Women and men in the informal economy: a statistical brief", available at: https://www.ilo.org/wcmsp5/groups/public/—ed_protect/—protrav/—travail/ documents/publication/wcms_711798.pdf (accessed 22 August 2019).

International Trade Union Confederation (ITUC) (2020), "Putting people first: 12 governments show the world how to protect lives, jobs and incomes", available at: https://www.ituc-csi.org/puttingpeople-first (accessed 20 April 2020).

Kahneman, D. and Tversky, A. (1979), "Prospect theory: an analysis of decision under risk", Econometrica, Vol. 47 No. 2, pp. 263-291.

Katz, L.F. and Kreuger, A.B. (2019), "The rise and nature of alternative work arrangements in the United States, 1995-2015”, ILR Review, Vol. 72 No. 2, pp. 382-416.

Kirchler, E. (2007), The Economic Psychology of Tax Behaviour, Cambridge University Press, Cambridge.

MacDonald, R. and Giazitzoglu, A. (2019), "Youth, enterprise and precarity: or, what is, and what is wrong with, the 'gig economy'?", Journal of Sociology, Vol. 55 No. 4, pp. 724-740. 
IJSSP

$40,9 / 10$

1018

Mathias, B.D., Lux, S., Crook, T.R., Autry, C. and Zaretzki, R. (2015), “Competing against the unknown: the impact of enabling and constraining institutions on the informal economy", Journal of Business Ethics, Vol. 127 No. 2, pp. 251-264.

McDonough, B. and Morales, J.B. (2020), Universal Basic Income, Routledge, London.

McKerchar, M., Bloomquist, K. and Pope, J. (2013), "Indicators of tax morale: an exploratory study", eJournal of Tax Research, Vol. 11 No. 1, pp. 5-22.

Medina, L. and Schneider, F. (2018), "Shadow economies around the world: what did we learn over the last, 20 Years?", IMF Working Paper WP/18/17, available at: https://www.imf.org/ /media/ Files/Publications/WP/2018/wp1817.ashx (accessed 22 August 2019).

Murphy, K. (2005), "Regulating more effectively: the relationship between procedural justice, legitimacy and tax non-compliance", Journal of Law and Society, Vol. 32 No. 4, pp. 562-589.

North, D.C. (1990), Institutions, Institutional Change and Economic Performance, Cambridge University Press, Cambridge.

Office for National Statistics (ONS) (2020), "Furloughing of workers across UK businesses: 23 March 2020 to 5 April 2020", available at: https://www.ons.gov.uk/employmentandlabourmarket/ peopleinwork/employmentandemployeetypes/articles/furloughingofworkersacrossukbusinesses/ 23march2020to5april2020 (accessed July 2020).

Papoutsaki, D. and Wilson, T. (2020), Covid-19 and the Low Paid: Early Analysis of Labour Force Survey, Briefing, IES, Brighton, available at: https://www.employment-studies.co.uk/system/ files/resources/files/IESbriefing-Covid-19andthelowpaidFINAL2_0.pdf (accessed 31 July 2020).

Portes, A. and Haller, W. (2005), "The informal economy", in Smelser, N.J. and Swedberg, R. (Eds), The Handbook of Economic Sociology, 2nd ed., Princeton University Press, Princeton, pp. 403-425.

Raijman, R. (2001), "Mexican immigrants and informal self-employment in Chicago", Human Organization, Vol. 60 No. 1, pp. 47-55.

Robbins, S.P., Coulter, M. and DeCenzo, D. (2017), Fundamentals of Management, 10th ed., Pearson, Harlow.

Sassen, S. (1994), "The informal economy: between new developments and old regulations", The Yale Law Journal, Vol. 103 No. 8, pp. 2289-2304.

Schneider, F. (2011), "The Shadow Economy Labour Force: what do we (not) know?", World Economics, Vol. 12 No. 4, pp. 53-92.

Schneider, F., Buehn, A. and Montenegro, C.E. (2010), "New estimates for the shadow economies all over the world", International Economic Journal, Vol. 24 No. 4, pp. 443-461, doi: 10.1080/ 10168737.2010.525974.

Shapland, J. and Heyes, J. (2017), "How close are formal and informal work?", International Journal of Sociology and Social Policy, Vol. 37 Nos 7/8, pp. 374-386.

Simpson, W., Mason, G. and Godwin, R. (2017), "The Manitoba basic annual income experiment: lessons learned 40 Years later", Canadian Public Policy, Vol. 43 No. 1, pp. 85-104.

Stuart, E., Samman, E. and Hunt, A. (2018), Informal Is the New Normal. Improving the Lives of Workers at Risk of Being Left behind, Overseas Development Institute, London, available at: https://www.odi.org/sites/odi.org.uk/files/resource-documents/11993.pdf (accessed 22 August 2019).

Suchman, M.C. (1995), "Managing legitimacy: strategic and institutional approaches", Academy of Management Review, Vol. 20, pp. 571-610.

Trade Union Congress (TUC) (2008), "Hard work, hidden lives: the short report of the commission on vulnerable employment", available at: http://www.vulnerableworkers.org.uk/files/CoVE_short_ report.pdf (accessed 22 August 2019).

Trade Union Congress (TUC) (2017), "The gig is up: trade unions tackling insecure work", available at: https://www.tuc.org.uk/sites/default/files/the-gig-is-up.pdf (accessed 22 August 2019). 
United Nations (UN) (2017), “General assembly resolution 70/1 of, 25 september, 2015”, available at: http://www.un.org/ga/search/view_doc.asp?symbol=A/RES/70/1\&Lang=E (accessed 22 August 2019).

Università di Pisa (2020), Towards a Caring Democracy, European Law and Gender Blog, April 2020, available at https://elan.jus.unipi.it/blog/towards-a-caring-democracy/ (accessed 31 August 2020).

Webb, J.W., Tihanyi, L., Ireland, R.D. and Sirmon, D.G. (2009), "You say illegal, I say legitimate: entrepreneurship in the informal economy", Academy of Management Review, Vol. 34 No. 3, pp. 492-510.

Webb, A., McQuaid, R. and Rand, S. (2019), "What, who, why and ways out of the informal economy: a brief review of key definitions and approaches", in Larsen, C., Rand, S., Schmid, A., Bobkov, V. and Lokosov, V. (Eds), Assessing Informal Employment and Skills Needs: Approaches and Insights from Regional and Local Labour Market Monitoring, Rainer Hampp Verlag, Munich, pp. $23-40$.

Williams, C.C. and Horodnic, I.A. (2016a), "An institutional theory of the informal economy: some lessons from the United Kingdom”, International Journal of Social Economics, Vol. 43 No. 7 , pp. 722-738.

Williams, C.C. and Horodnic, I.A. (2016b), "Tackling the undeclared economy in the European Union: an evaluation of the tax morale approach", Industrial Relations Journal, Vol. 47 No. 4, pp. 332-340.

Williams, C.C. and Kayaoglu, A. (2020a), "COVID-19 and undeclared work: impacts and policy responses in Europe", The Service Industries Journal, Vol. 40 Nos 13-13, pp. 914-931, doi: 10. 1080/02642069.2020.1757073.

Williams, C. and Kayaoglu, A. (2020b), "The coronavirus pandemic and Europe's undeclared economy: impacts and a policy proposal", The South East European Journal of Economics and Business, Vol. 15 No. 1, pp. 80-92.

Williams, C.C. and Martinez, A. (2014), "Do small business start-ups test-trade in the informal economy? Evidence from a UK survey", International Journal of Entrepreneurship and Small Business, Vol. 22 No. 1, pp. 1-16.

Williams, C.C. (2011), "Reconceptualizing women's and men's undeclared work: some results from a European union survey”, Gender, Work and Organization, Vol. 18 No. 4, pp. 415-437.

Williams, C.C. (2014), "Out of the shadows: a classification of economies by the size and character of their informal sector", Work, Employment and Society, Vol. 28 No. 5, pp. 735-753.

Williams, C.C. (2020), "Impacts of the coronavirus pandemic on Europe's tourism industry: addressing tourism enterprises and workers in the undeclared economy", International Journal of Tourism Research, pp. 1-10, doi: 10.1002/jtr.2395, (accessed 16 August 2020).

Women in Informal Employment: Globalizing and Organizing (WIEGO) (2020), "Informal worker demands during COVID-19 crisis", available at: https://www.wiego.org/informal-workerdemands-during-covid-19-crisis (accessed 31 August 2020).

\section{Corresponding author}

Ronald McQuaid can be contacted at: ronald.mcquaid@stir.ac.uk

For instructions on how to order reprints of this article, please visit our website:

www.emeraldgrouppublishing.com/licensing/reprints.htm

Or contact us for further details: permissions@emeraldinsight.com 